\title{
UNDOCUMENTED BIRDS: ECHOPOLITICS AS INTERSPECIES RESISTANCE
}

Nuno da Luz ${ }^{1}$

Lisboa, Portugal

Departing from the study of today's populations of monk and ring-necked parakeets (endemic to South America and South Asia, respectively) inhabiting three Southern European cities - Athens, Madrid, and Lisbon -, this essay articulates together the tensions arising from their classification as invasive alien species with the transformation of these cities' soundscapes. As different administrative bodies in Europe are preparing these birds' population control through biopolitical management (i.e. extermination and sterilization), the cries and calls of these exotic birds speak loudly about the mutable nature of our environments, urban and otherwise. Difficulties of representing complex processes of environmental change entail the necessity for enacting modes of attention where noise-making and listening are tools that ready both humans and non-humans as noisy resistants to the enforced silencing brought on by late capitalist exploitation forms.

Keywords: exotic parakeets, invasive alien species, transplants, politics of noise, post-colonial soundscapes, echopolitics

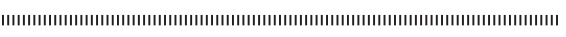

Track 1: Athens September 2017

https://archive.org/download/undocumented-birds/Track01.mp3

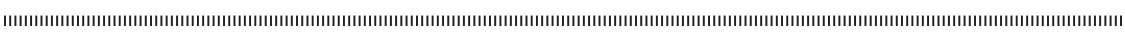

The recording above documents five minutes at the National Gardens in Athens, Greece, as heard one late afternoon in September 2017. Nowadays a public park, it was originally designed as a Botanical Garden belonging to the old Royal Palace - the building housing today the Greek Parliament, facing the iconic Syntagma Square. Recorded as the sun was setting, we hear strong stepping sounds from joggers running around the park, and the voices of visitors passing by. The continuous low-frequency hum of city traffic at a distance is strongly felt throughout, with several car and motorcycles revving up from time to time. Occasionally,

1 Email: nuno@echologi.es 
cicadas join in. But the loudest captured sounds are the high-pitched callings of Ring-necked parakeets. Nesting in large groups in the canopy of tall trees in the park, their cries register high in the frequency range. And at that specific moment of the day, and of the year, seemed to have little competition from other birds within that part of the spectrum.

Native to certain parts of Africa and the Indian Subcontinent, Ring-necked Parakeets, Psittacula krameri, have found their way to Athens (and other parts of Europe) not by traditional migratory routes - they're incapable of flying such distances - but by having been brought to be sold and kept as pets. Either escaping captivity or voluntarily released by their former owners, many of these birds managed to adapt, find shelter, food, and partners; and thus thrive in otherwise foreign habitats. We can count several generations in Athens alone, but recordings similar to this one could have been made in many other European cities over the last four decades.

These parakeets - along with several other species that range between parrots and budgerigars - have become an almost ubiquitous presence in the whole of Southern Europe, with populations recorded all throughout the Mediterranean. Certain species can be also found further North: London registers some of the biggest European populations and other groups inhabit Ireland, the Netherlands, and Belgium. ${ }^{2}$ One of the most infamous communities of Ring-necked Parakeets in Europe has lived in Brussels for several decades now: an aviary at the Meli Heysel Park, near the Atomium, regularly released domesticated parakeets out into the open, between 1974 and 1987.3

Another species, the Monk parakeet, Myiopsitta monachus, has also considerably grown in numbers these past few years, with tens of thousands of birds living in the Iberian Peninsula. Larger communities concentrate mainly in Madrid and Barcelona, but can also be found in Lisbon and Porto. Endemic to South America, where it is found from Bolivia to Patagonia, they are commonly called Cotorra argentina in Spanish, given their place of origin. In Spain, it is even considered a pest, with the Madrid's City Hall advancing an extermination programme that was set to start in October 2020. Given a succession of events it is still in the works: first delayed by the lockdown and confinement measures of Spring 2020, then by judicial injunctions on the signed contracts, and more recently the 'Filomena' blizzard felt in January 2021 - that registered the heaviest snowfall of the past 50 years and has likely harmed and disrupted parakeet populations, along with many other species, due to pervasive damage to trees around the city. Still - by $15^{\text {th }}$ February 2021 - the City Hall has reiterated their plan to hunt and kill around 12,000 Monk parakeets, in order to contain and control their population below a threshold considered disruptive to the local ecosystem (Aísa 2019, Fernández 2021). Such programme can only take place as both Monk and Ring-necked parakeets, along with several other exotic bird species, are biologically classified as Invasive Alien Species in Europe:

Plants, animals, pathogens and other organisms that are non-native to an ecosystem, and which may cause economic or environmental harm or adversely affect human health. In particular, they impact adversely upon biodiversity, including decline or elimination of native species - through competition, predation, or trans-

$2 \quad$ For updated information on populations and sightings, please check the ParrotNet Monitoring Centre for non-native psittacidae species. Available at <https://www.kent.ac.uk/parrotnet/map.html>, accessed 2021-02-26.

3 The Ornithological Commission of Watermael-Boitsfort. Available at <http://www.cowb.be/wp-content/ uploads/2014/05/perruches.pdf>, accessed 2021-02-26. 
mission of pathogens - and the disruption of local ecosystems and ecosystem functions. ${ }^{4}$

According to ParrotNet - the European Network on Invasive Parakeets - these two species are among the "top 100 worst alien species in Europe" where they have "begun to pose problems in urban and rural areas such as disturbance to humans, competition with native wildlife and, increasingly as an agricultural pest." But it's their naturalisation within local ecological niches that shows why their populations have been growing in the past few decades; and have now reached proportions where government bodies and scientific institutions feel they have to forcefully intervene and manage the unbalanced ecosystems of some of the biggest cities in Europe. According to ParrotNet:

[F]arming practices that adapt to global climate change and a warmer Europe facilitate the continued expansion of parakeet populations, amplifying the problems parakeets pose for European agro-economy. [...] Farming practices will increasingly have to adapt to warmer climates; for example, maize, pecan nuts and sunflower will become more popular crops as mean temperatures rise. Parakeets are widely documented as being a pest of these crops, reducing maize yields by up to $81 \%$ in their native range. [...] Therefore, climate-driven expansion of parakeet populations across Europe will place increasing pressure on the economy. ${ }^{5}$

Their acclimatisation is taking place in tandem with temperatures rising all around the globe; courtesy of the disruptive effect of industrial and extractive activities, and consequent increase in greenhouse gases' emissions. Along with many other factors, ParrotNet tells us explicitly that as Europe's climate starts to increasingly resemble the ones endemic to these birds, there will be no change to the agro-economic plantation model, that led us to our current environmental predicament. Biological and specist eugenics (population control through number management) will be one of the first measures to be enacted, preferring to leave systemic environmental catastrophe and its causes unaddressed. Even if ParrotNet acknowledges eradication as "too costly or even impossible", it hasn't proposed alternative mitigation strategies as part of their recommendations policy. ${ }^{6}$ Whilst seemingly failing to account for the disruptive effects of climate change besides its most immediate agro-economic issues, it also shows a lack of countering classical notions of Invasive vs. Native species, such as a more neutral terminology would. For example, Robert I. Colautti and Hugh J. MacIsaac advance that:

Many important terms relevant to invasion ecology theory, like "invasive", "weed", or "transient", include qualities that are open to subjective interpretation. (...) [T]erms like "nuisance" may have more to do with human perception than with any inherent ecological characteristics (Colautti, MacIsaac, 2004: 135).

Their effort attempts to minimize common prejudices and pitfalls when conducting studies on ecology networks, that have hitherto overlooked the importance that discourse and language have on understanding and comprehending their subjects. The difficulty in articulating other terms to describe the current invasion of European milieus by these parakeets is clear, not only in ParrotNet's policy recommendations, but also in the way they mirror Madrid's City Hall rhetoric as advised by SEO/Birdlife (the Spanish Ornithology Society, Sociedad Española de Ornitología). SEO actually recommends "capturing and exterminating" in order to contain parakeet populations. So far, the only other public policy campaign has been PACMA's (a

4 "Invasive Alien Species" terminology from the United Nations Convention on Biological Diversity. Available at <https://www.cbd.int/idb/2009/about/what>, accessed 2021-02-26.

5 In the About ParrotNet section. Available at <https://www.kent.ac.uk/parrotnet/aboutparrotnet.html>, accessed 2021-02-26.

6 ParrotNet Policy Briefing "Invasive Parakeets in Europe: Problems and Solutions". Available at <https:// www.kent.ac.uk/parrotnet/policybrief/policies/ParrotNet_English.pdf>, accessed 2021-02-26. 
Spanish political party advocating animal's rights) attempt to defend a "capture and sterilization" programme, that would allow populations to decrease over time (Palou 2020).

Common to all these proposals is the failure to acknowledge the intricate web of relations between the contemporary global economy and global ecology, as the International Union for Conservation of Nature has tried to, by promoting an alternative notion of Invasive Alien Species as species:

[I]ntroduced, accidentally or intentionally, outside of their natural geographic range and that become problematic. They are often introduced as a result of the globalisation of economies through the movement of people and goods, for instance via shipping, consignments of wood products carrying insects, or the transport of ornamental plants to new areas. ${ }^{7}$

As their transplanting to Europe attests, these parakeets are clear examples of how global trade today implicitly follows old colonial bonds, that continue to be at once fostered and invisible. A long and unequal process of planting and transplanting humans and non-humans alike, that started centuries ago, and continues to this day; central to the many concurrent crises facing us today. The introduction of a concept such as the Anthropocene (with all of its shortcomings ${ }^{8}$ ) - beyond advocating a change in geological epoch ushered by human activity as a dominant Earth-shaping force - has forced a more general reconsideration of the natural/ cultural divide. Human and non-human realms can no longer be seen or conceived as separate from each other, nor can nature continue to be thought of as an independent concept. Such a critique in terms of native/invasive discussions can be clearly seen in the article "Botanical Decolonization" (2014) by researchers Tomaz Mastnak, Julia Elyachar and Tom Boellstorf. While specifically concerned with the vegetal, it also resonates with other human/non-human entanglements. In their words:

Charging native plant enthusiasts and invasion biologists and managers with xenophobia has practical consequences (Simberloff 2003: 184).

The native plant movement is not about whether or not we should fight immigrants, or interfere with evolutionary processes. Rather, the question is how we should deal with the intended changes and unintended consequences of the Anthropocene (Boellstorf, Elyachar, Mastnak, 2014: 372, 374). [I would argue "Plantationocene"

And continuing further below:

Treating plants metaphorically only as immigrants [arguing for exotics and botanical cosmopolitanism], but never as settlers [the plantation], paradoxically divides human from nature. It eludes the forms of displanting - of botanical colonization - that were part and parcel of the colonial encounter (Boellstorf, Elyachar, Mastnak, 2014: 374).

$7 \quad$ IUCN International Union for Conservation of Nature notion of Invasive Alien Species. Available at $<$ https://www.iucn.org/regions/europe/our-work/biodiversity-conservation/invasive-alien-species>, accessed 2021-02-26. I thank the precious work of peer reviewers that brought this to my attention.

8 Best exemplified in the seminal critique of Paul Crutzen and Will Steffen by Donna Haraway "Anthropocene, Capitalocene, Plantationocene, Chthulucene: Making Kin.” doi: 10.1215/22011919-3615934.

9 For an in-depth conversation on the topic please see "Reflections on the Plantationocene: A Conversation with Donna Haraway and Anna Tsing", Edge Effects: The Plantationocene Series - Plantation Worlds, Past and Present. Available at <https://edgeeffects.net/wp-content/uploads/2019/06/PlantationoceneReflections_Haraway_Tsing. pdf $>$, accessed 2021-02-26. 
The exotic calls of the different parakeets populating the sonic space of European cities attest to the ongoing environmental change, brought forth by the reduction of other ecosystems around the planet. Both intended and unintended, these shifts are at the forefront of a world necessarily smaller, poorer, and more alike; documented in the decreasing numbers of biodiversity shared by scientists, with a sixth mass extinction well underway (Ceballos, Ehrlich, Raven 2020: 13596). But the transformed and enriched nature of these new aural environments - collapsing the animal soundscapes of India, Africa, South America and Europe together - shows how uncontrollable are the transits and modes of reclaiming another inhabitation of the world. As much as the history of European exceptionalism tries to contain and efface the agency of the subjugated - and the necessarily two-way exchange that still holds even in relations of subservience - the raucous and noisy songs of such "Invasive Alien" birds remind us of the efforts to muffle and conceal the myriad displaced and immigrant communities around Europe. Their struggle for recognition also reflects the impoverishment and exploitation of their places of origin. Resisting against institutionalised racism and xenophobia, these communities have founded new understandings of multiculturalism and polyphony, that helped expose nationalist and supremacist narratives. It has also exposed the fraught nature of europe's founding tale: one based on erasing difference within its "fortress" borders, and never assuming its multicultural construct. Parakeets along with undocumented migrants, refugees, and asylum seekers, hailing from what has been called "the outside" have long been living within. But keep being pegged as foreigners against which the "old world" needs to fortress, against such barbarians. That these barbarians are not only black and brown but also green gives us a chance, voiced by researcher Baptiste Morizot, to put into question the foundations of an ontology that has led us to our current situation:

This relation of ecological competition, of mutual disturbance (...) has been coded as a war, and later the victory was theorised as progress and civilisation. [...] We can doubt the foundations of such attitude because it destroys without a doubt, in its recent forms, the biosphere and puts our existence on Earth in peril: it also gives us the opportunity - through its failure - to see the construct of our most foundational ontological chart. A metaphysics may be refused if it renders the world uninhabitable (Morizot 2016: 78). ${ }^{10}$

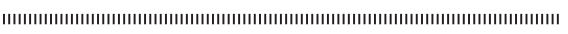

\section{Track 2: Madrid December 2019 https://archive.org/download/undocumented-birds/Track02.mp3}

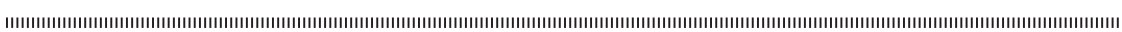

Fast-forwarding to Madrid, the recording above was made in a late Autumn morning at one of the most congested roads crossing the city centre. The Paseo del Prado houses several central administration buildings - the City Hall, the Navy, etc. - but most famously the Prado Museum and the Botanical Gardens. Lining the Museum, we find tall pine and cedar trees where Monk parakeets nest. Each nest can host up 40 or 50 different couples in what are actual parakeet buildings: intricate constructions that can weigh up to 40 or $50 \mathrm{~kg}$, and have been deemed a public health hazard, if they were to fall on someone's head. According to Madrid's City Hall, none have fallen yet but it's cited as one of their main concerns. In the current cabinet's enforcing of a (necro)biopolitics against the increasing populations of local cotorras, we see how their predisposition towards a technocratic solution is still predicated on an old false dichotomy between good and bad. The new conservative cabinet took office in May 2019 with the support of the far-right - and readily announced, as one of their first environmental measures, the parakeets' extermination programme, aiming at reducing the current population

10 Ed.-Translated from the French by the author. 
by at least $90 \%$. According to Borja Carabante, the Environment and Mobility Delegate of Madrid's City Hall:

We have to understand that the environment is not all the same, and that there are good ones and bad ones, and that the ones who come from outside, in an aggressive manner, well, unfortunately can't be here and don't have the same ecological right to life that we all have; they are not where they should be and cause damages (Aísa 2019). ${ }^{11}$

The overt tones of human exceptionalism seem clear, with deeming certain lives more valuable than others included in such a public address. Such prerogative is described by Morizot, when talking about a similar conundrum facing the return of wolves to France, an "impossible management":

At first, the political solution seems to boil down to the zoo-technical management of a new phenomenon, by ecological experts. But the traditional models of ecological management of the wild are failing: the first and oldest model, the regulation of populations by hunting, is the zoo-technical panorama of "biopower", following the concept by Michel Foucault. It can lead up to extermination in the case of "disruptors", such as the case of the wolf in the early twentieth century (Morizot 2016: 20). ${ }^{12}$

But it is increasingly harder to defend such an anachronistic position today, when increasingly traditional anthropocentric (usually Western) ethics are supplanted by more bioand eco-centric modes of thinking. Still, it should come as no surprise. The geographer Paul Robbins, studying so-called invasive processes and networks, refutes such life-and-death instances of misused biopower to state that:

The status and identification of any species as an invader, weed, or exotic, are conditioned by cultural and political circumstances (...). It is not species but sociobiological networks that are invasive (...). Invadable landscapes do tend to be heavily disturbed (...) and to have simplified plant communities with relatively less native biodiversity (Robbins 2004: 140).

I would argue that Madrid might just be the case in point: it's historically deprived of a specific relation with its immediate surroundings - the imperial capital of a huge colonial project on a dry plateau. In it, displaced agents in the form of winged creatures appear to signify that which settler mentality hasn't been able to silence or deny. One of the most cited instances of Monk parakeets' disturbance of Madrid's ecosystem is the disappearance of sparrows, one of the most common bird species living in European urban areas. They're said to be aggressive towards them or take up nidification spaces that sparrows would traditionally use. And sparrows are disappearing at an alarming rate from most cities in Europe: in Madrid alone, it is possible that a million sparrows are now gone (nuevatribuna.es 2019). Experts say that among those reasons, competition with exotic species for the slim ecological niches left in towns is one of the reasons. But they also count atmospheric pollution, massive tree felling or logging (as more and more space is lost to new construction), the closing of tree holes and pits for fear these may help spread fungi and other plant diseases, the use of inappropriate pesticides that may be killing insect populations that would otherwise be food for sparrows, along with the difficulty of nesting in current buildings that lack holes and sheltering features that sparrows could use. ${ }^{13}$

11 Ed.-Translated from the Spanish by the author.

12 Ed.- Translated from the French by the author.

13 SEO/BirdLife Report on common sparrows in Spain. Available at <https://www.avesdebarrio.seo.org/ wp-content/uploads/2019/03/Informe_gorrion_AvesDeBarrio.pdf>, accessed 2021-02-26. 
Just as it is the case in Athens, Madrid's current parakeets' populations can be traced back to their popularity as pets in the 1980s and 90s. The first official registry of this commerce dates back to 1986. According to the head of Madrid City Hall's Biodiversity Division, Santiago Soria Carreras, "They ended up in parks because owners would get tired [Monk parakeets have a lifespan of approximately 20 years] and would released them, or they themselves would escape" (Aísa 2019). ${ }^{14} \mathrm{He}$ continues on to say that, "They're very clever animals, that adapt easily to conditions that are not their original ones. They have adapted because they're very intelligent. Besides, they feed on many things and scavenge any leftovers of food or plants" (Aísa 2019). ${ }^{15}$ And according to Juan Carlos del Moral - a biologist working with SEO/Birdlife, "[They are] very difficult to capture. They're extremely smart and social animals and they warn each other, so if you capture one of a flock, you will no longer be able to hunt another in weeks" (Torres 2020). ${ }^{16}$

The multi-partner congregations of 40 to 50 couples found in their biggest nests - although several live in smaller groupings - do not only bring multi-storey buildings to mind, but also towns. They're actual active networks, whose flocks maintain a constant noise flow, proportional to their social cohesion, with constant calls reaffirming and tending to a colony's own sense of close association and wellbeing (Martella, Bucher 1990: 101). ${ }^{17}$ Discussing the Monk parakeets' ecology and ethology with members of the Cultural Ecologies group of MACBA's 2019 Independent Studies Programme, they mentioned that the continuous racket of the cotorras entails other ways of thinking about communication: their cries and calls are not so much clear messages but a form of keeping communication channels open and flowing. ${ }^{18}$ To keep these channels hot means feeding them with signals, indifferent to the signal-to-noise ratio of the medium. To paraphrase an ethological Marshall McLuhan, noise is the message. Here, communication is based more on rhythm than so-called content. Raucous noise filling up ambient space with sound is heavy with meaning, and a steady and healthy exchange amounts to both information and affect. In their exhibition "Plaga" at MACBA, the Cultural Ecologies group has espoused an approach to the Monk parakeets' position in current interspecies entanglements in Spanish cities, that draws from their lively and loud community-through-sound to counter the normative, arithmetic, and economic notions of pest attached to them. Cultural Ecologies' video Loros rebeldes (rebel parrots) collects a multitude of formats (interviews, memes, animal recordings, news, and others) to create a polyphonic and complex portrayal of the current eco-political status of the cotorras, that alludes to the conflicted relations between life and territory that we can witness in Europe today. ${ }^{19}$ It also attests to the importance of noise-making: who or what is allowed or unable to join our sonic territories? If for the Monk parakeets, their constant noise stream signals the soundness of their colonies, then any transmission drop is also heavy with meaning: silence is as important and telling as any cry or shriek, as it may imply an impending threat or danger. And it is here that natural/cultural misunderstandings again come to the fore. Quoting Santiago Soria Carreras, once more, "They make noises considered annoying, transmit diseases to other birds, eat their food (...). So far, the nests haven't caused

14 Ed.-Translated from the Spanish by the author.

15 Ed.-Translated from the Spanish by the author.

16 Ed.-Translated from the Spanish by the author.

17 I thank the editors for bringing this article to my attention.

18 I thank Maíra das Neves, José Platzeck and Rafael Frazão along with all the other members of the Ecologias Culturales group, within MACBA Independent Study Program PEI for all the insights shared and exchanged during the Microhabitable Workshop, at Matadero Madrid, December 2019.

19 "Plaga" exhibition brochure. Available at <https://www.macba.cat/en/exhibitions-activities/exhibitions/ plague>, accessed 2021-02-26. 
any harm to people, but the administration has received 197 complaints from neighbours [due to noise] from January to August 2019" (Aísa 2019). ${ }^{20}$

We can clearly hear the historical echoes of such rhetoric, proffered for centuries against foreign communities. There hasn't been a colonial power who hasn't characterised the subjugated's language, oral customs and culture as noisy. But as stated in a famous poster pasted up on walls from São Paulo to Lisbon by Coletivo Transverso: "The Portuguese didn't arrive in Brazil speaking softly." ${ }^{21}$ Confined to his apartment in Madrid and looking out the window, during the forced quarantine following the spread of the SARS-CoV-2 coronavirus in early 2020, researcher José Luis Espejo framed this as such: "Silence is a cultural construct that does not mean absence of noise, but a system under which to manage it" (Espejo 2020). ${ }^{22}$

The controlled killings of Monk parakeets in Madrid - besides the huge loss of life, that should entail a necessary reckoning with the real consequences of globalisation - will come to a new silencing. This is a powerful reminder of the inability of past and present-day Western institutions to listen to the Other, whether we are talking about another species or peoples. Most indigenous peoples were deemed incomprehensible and hence savage; deemed silent by those who wished to silence them. Here, the enemy is still the Wild, or better yet the domesticated-turned-feral, as in the case of these-once-pets now considered "Invasive Aliens". Their acclimatisation and adaptation within the borders of "Fortress Europe" amounts to a sort of resistance: noisy obstacles to total sovereignty. And as such, they are suffering continuous repression through regulation, control, and possibly facing extermination or sterilization.

Such relations of power and domination always entailed their opposite as well, with the pervasive introduction of sounds brought on by European colonization, in different parts of the world. Researcher Mayra Estévez Trujillo has called it "the colonial regime of sonority". The extractivist-industrial complex at work in colonized territories - relying on slave and semi-slave workforces - changed everything, and consequently, the acoustic soundscapes of entire continents. In Mayra Estévez Trujillo's research - as referred to by José Luis Espejo - we find the reversals of the Monk and Ring-necked parakeets invasion: one god, one language, the barking of dogs introduced by European colonisers, the oil extraction facilities run by corporations based in the Unites States of America, and the engine noise of Japanese Honda scooters ubiquitous in Peru (Trujillo 2016): "The colonial regime set the bases for the conceptual separation of peoples and nature, it privileged that part of humanity deemed human and divine-like in its mandate to exploit other people and organisms in the planet" (Espejo 2020). ${ }^{23}$

Colonisation transformed life in its myriad forms, with extreme violence. Today we sense such process as a hidden infrastructure regulating our modes of communicating and listening: to be loud and occupy sonic space at our own peril, or self-censor and keep quiet in order to survive. Silence has been historically weaponised by autocratic and military regimes, where expressing dissent was severely repressed, or ingeniously masked to avoid reprisals.

20 Ed.-Translated from the Spanish by the author.

21 A collective of artists hailing from Brazil that use banned forms of public intervention, such as graffiti and wheat-pasting, as a way to engage the urban sphere poetically. More information available at <https://www.coletivotransverso.com.br/>, accessed 2021-02-26.

22 Ed.-Translated from the Spanish by the author.

23 Ed.-Translated from the Spanish by the author. 
In our newfound condition under a global pandemic - with streets becoming deserted, first in China and subsequently all around the world; with social distancing and lockdown rules being enforced internationally; with interpersonal communication more easily surveilled through virtual chats and video calls - we are led to equate the silence of a momentarily-halted economy with the return of the natural. With people off the streets, cars parked, and airplanes grounded, ambient sound - for those who were in the privileged position of doing less and listening more attentively to what surrounds them - seemed louder. It felt as if our planetary co-inhabitants thrived. But such effect is well known to acousticians as noise masking. Whenever we find ourselves in an environment of loud constant drones and these suddenly stop, we tend to feel as if silence has set. The perceived drop coming from the fact that as we grow accustomed and naturalise certain noises, their absence feels like a void, since they stop masking other sounds. The quarantine and lockdown measures carried through all around Europe emulated this masking effect: with the constant drone of human activity toned down to a minimum, it became easier to parse different presences and realise the variety of a low-intensity sonic environment. It is terribly absurd then that such perception comes at the behest of huge human suffering, such as the ongoing pandemic and its reenforcement of violent systems of social control.

As I write in Lisbon in February 2021, almost all airplanes are grounded once again. Mirroring 2020's travel restrictions, borders have again been closed in a frenzied panic - although this time the Schengen agreement has continued to be observed among its European Union co-signees, contrary to last year's lockdown. Diplomatic reciprocity is taking prevalence once more: flights are only allowed to take off from destinations known to accept reciprocal landings. During the last picking season, in what may even seem like a crude economic joke, hundreds of people (mostly men) were mobilised and flown from least "developed" European countries like Romania and Bulgaria, to take up seasonal jobs in agriculture - as they have been doing for decades - in countries such as the UK and Germany. Visa-waiver programmes in place made sure picking season would go on as planned, and governments took care these workers returned home once work was finished; all the while unobserving many of the strict regulations and social distancing rules that would keep workers healthy, and keeping their own local workforces in quarantine (Espejo 2020).

Two years ago the situation was understandably different, but altogether off scale. When out to record Monk parakeets in Lisbon, I was made acutely aware of the relentless rhythm of air traffic in the city. Statistics pointed towards an average of four minutes between each landing, and four minutes between take-offs - sensibly two minutes between each as planes alternate on Lisbon's sole runway. Inaugurated in 1942, its location turned from city outskirts to being surrounded by dense residential areas. The nearest ones are still traditionally lower-income households but that has rapidly changed. The end of austerity measures enforced by lenders (European Central Bank, International Monetary Fund, and European Union) between 2011 and 2015, stimulated the city's booming construction and gentrification, after an economic collapse that followed the world banking and financial crisis of 2008. With it, a massive influx of tourists - predicated on low-cost air travel and the rise in short-term rentals primed by platforms such as Airbnb - seemed to sweep a city and a country where public and private 
investment was almost exclusively funnelled towards real estate speculation and holdings. ${ }^{24} \mathrm{The}$ increase in air traffic noise has not been addressed publicly by any of the administrative bodies, and the last noise study focussing on the city of Lisbon (without mentioning its suburbs and environs) dates from 2015 - immediately before the boom in mass tourism and air travel. It accounts mostly for road traffic and the approach "corridor" for airplanes to land at the airport, that hovers directly above the city in a southwest-northeast direction. Their noise is felt all the way from the river to the airport, a route measuring around $18 \mathrm{~km}$ in length, flying over some of the most densely populated areas of town. ${ }^{25}$ What this map does not account for are questions of rhythm and intensity. While recording parakeets in three locations, all in the vicinities of the airport - Quinta das Conchas, Campo Grande, and Parque de Saúde de Lisboa (previously a psychiatric hospital, still housing several psychiatric wards today, among other health facilities and institutes) - I found their callings straining to hear (or anything else really), as every four minutes in average, the deafening roar of airplane turbines would drown all other sounds out. As a lasting statement to that clear and loud example of turbo capitalism, I leave you with a recording done on 13 June 2019. The day after the biggest local festivities take place - in what is traditionally a city-wide party lasting overnight - the city is quieter than usual, with foot and road traffic almost standing to a halt. But the holiday observed that day in Lisbon meant little in terms of international calendars. As the city found itself hungover from the excesses of the previous night, airplanes kept coming every four minutes in average, from 8am to 8pm. With little else urban noise to compete with, parakeets found themselves competing alone with these great beasts of gravity: steel "birds" running on oil, that cater to the same influx of free trade and movement that has first brought Monk and other parakeets to Europe. That same status quo is now vying to outlaw them, according to conservationist tenets that equate invasive species, undocumented aliens, and animals without papers that will never keep quiet. ${ }^{26}$

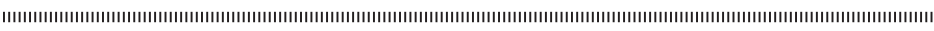

Track 3: Parque de Saúde de Lisboa, Lisbon, June 2019

https://archive.org/download/undocumented-birds/Track03.mp3

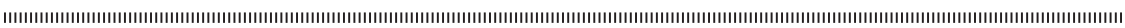

\section{BIBLIOGRAPHY}

Aísa, Lucía Ramos. 2019. "Madrid eliminará la mayoría de las 12.000 cotorras invasoras que amenazan el ecosistema de la ciudad", El Pais, 2019-10-08. Available at <https://elpais. com/ccaa/2019/10/07/madrid/1570443327_282116.html>, accessed 2021-02-26.

24 For a more in-depth analysis, please refer to the research of António Brito Guterres, such as "Lisbon in Late (Turbo) Capitalism”. Available at <https://www.academia.edu/37567281/LisboninLateTurboCapitalism>, accessed 2021-02-26.

25 Lisbon City Hall Environment Section: Noise. Available in Portuguese only at <https://www.lisboa.pt/ cidade/ambiente/qualidade-ambiental/ruido>, accessed 2021-02-26.

26 "Animals without papers" is my own translation of animales sin papeles from the Spanish: an expression I have learned from the Ecologias Culturales group (Luna Acosta, Renan Araujo, Bia Bittencourt, Rafael Frazão, Karen, Ánxela Louzao, Maíra das Neves, José Platzeck, Lucas Pretti and Marguerita Isola) in MACBA’s 2019 Independent Study Programme. Under that banner, they have been following and understanding the trials facing cotorras and other (deemed) invasive species in Barcelona; and to whom I cannot thank enough for our exchanges. 
Boellstorf, Tom, Julia Elyachar and Tomaz Mastnak, 2014. "Botanical Decolonization: Rethinking Native Plants" in Environment and Planning D: Society and Space, 32: 363380. doi: 10.1068/d13006p.

Ceballos, Gerardo, Paul R. Ehrlich and Peter H. Raven, 2020. "Vertebrates on the brink as indicators of biological annihilation and the sixth mass extinction" in Proceedings of the National Academy of Sciences of the United States of America, 117 (24): 13596-13602. doi: 10.1073/pnas.1922686117.

Colautti, RobertI.,HughJ.MacIsaac.2004."A NeutralTerminology to Define 'Invasive Species”, Diversity and Distribution, 10 (2): 135-141. doi: 10.1111/j.1366-9516.2004.00061.x.

Espejo, José Luis, 2020. "Algunas herramientas para escuchar esta pandemia: calma, silencio y quietud”, Campo de Relampagos, 2020-04-05. Available at <https://campoderelampagos. org/critica-y-reviews/4/4/2020>, accessed 2021-02-26.

Espejo, José Luis, 2020. "Calma, silencio y quietud / II", Campo de Relampagos, 2020-05-16. Available at <https://campoderelampagos.org/critica-y-reviews/15/5/2020?rq=espejo>, accessed 2021-02-26.

Fernández, Rafael. 2021. "Las cotorras tienen los días contados”, La Razón, 2021-02-15. Available at <https:/www.larazon.es/madrid/20210215/mfpth4b2nngjzh6wlubyfncpoi. html>, accessed 2021-02-26.

Martella, Mónica B., and Enrique H. Bucher, 1990. "Vocalizations of the Monk Parakeet", Bird Behaviour, 8 (2): 101-110. doi: 10.3727/015613890791784290.

Morizot, Baptiste, 2016. Les Diplomates: Cohabiter avec les loups sur une carte du vivant. Paris: Éditions Wildproject.

Palou, Neus. 2020. "Las cotorras de Madrid están condenadas a muerte”, La Vanguardia, 202002-13. Available at <https://www.lavanguardia.com/natural/20200213/473526364236/ cotorras-madrid-exterminio-pacma-firmas-maltrato-animal.html>, accessed 2021-0226.

Robbins, Paul, 2004. "Comparing Invasive Networks: Cultural and Political Biographies of Invasive Species” Geographical Review, 94 (2): 139-156,. Available at <https://www.jstor. $\mathrm{org} / \mathrm{stable} / 30033968$ ? seq=1>, accessed 2021-02-26.

Simberloff, Daniel, 2003. "Confronting introduced species: a form of xenophobia?" Biological Invasions, 5: 179-192. doi: 10.1023/A:1026164419010.

Torres, V., 2020. "Madrid eleva de 100.000 euros a tres millones la partida para sacrificar a más de 11.000 cotorras" El País, 2020-02-13. Available at <https://elpais.com/ccaa/2020/02/12/ madrid/1581506063_297003.html>, accessed 2021-02-26.

Trujillo, Mayra Patricia Estévez, 2016. Estudios sonoros en y desde Latinoamérica: del régimen colonial de la sonoridad a las sonoridades de la sanación. Quito: Universidad Andina Simón Bolívar Sede Ecuador. 